\title{
Correction to: Assessing responsiveness of the EQ-5D-3L, the Oxford Hip Score, and the Oxford Knee Score in the NHS patient- reported outcome measures
}

Sujin Kang

\section{Correction to: J Orthop Surg Res (2021) 16:18 \\ https://doi.org/10.1186/s13018-020-02126-2}

Following publication of the original article [1], the author notified us that the Supplementary document should be updated.

The original article has been corrected.

Published online: 05 February 2021

\section{Reference}

1. Kang S. Assessing responsiveness of the EQ-5D-3L, the Oxford Hip Score,

and the Oxford Knee Score in the NHS patient-reported outcome measures. J Orthop Surg Res. 2021;16:18 https://doi.org/10.1186/s13018-020-02126-2.

The original article can be found online at https://doi.org/10.1186/s13018020-02126-2.

Correspondence: sujin.kang@imperial.ac.uk

The research was conducted in The Nuffield Department of Orthopaedics, Rheumatology and Musculoskeletal Sciences, University of Oxford, Windmill, Road, Headington, Oxford, OX3 7LD, UK.

Faculty of Medicine, Imperial College London, South Kensington Campus,

London SW7 2AZ, UK

C C The Author(s). 2021 Open Access This article is licensed under a Creative Commons Attribution 4.0 International License, which permits use, sharing, adaptation, distribution and reproduction in any medium or format, as long as you give appropriate credit to the original author(s) and the source, provide a link to the Creative Commons licence, and indicate if changes were made. The images or other third party material in this article are included in the article's Creative Commons licence, unless indicated otherwise in a credit line to the material. If material is not included in the article's Creative Commons licence and your intended use is not permitted by statutory regulation or exceeds the permitted use, you will need to obtain permission directly from the copyright holder. To view a copy of this licence, visit http://creativecommons.org/licenses/by/4.0/ The Creative Commons Public Domain Dedication waiver (http://creativecommons.org/publicdomain/zero/1.0/) applies to the data made available in this article, unless otherwise stated in a credit line to the data. 